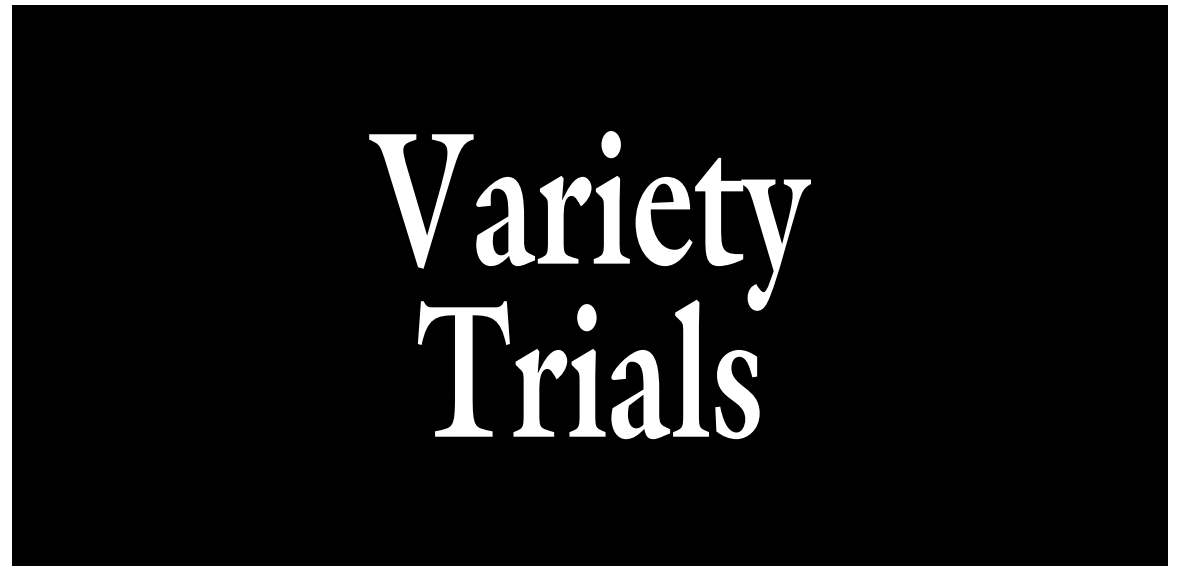

\section{Performance of 19 Pecan Cultivars and Selections in Southern Georgia}

\author{
Patrick J. Conner ${ }^{1}$
}

AdDitional INDEX wORDs. alternate bearing, Carya illinoinensis, quality, resistance, trial, variety, yield

$\overline{\text { SUMMARY. Nineteen pecan (Carya illinoinensis) clones were evaluated over a period }}$ of 18 years in a test orchard located in southern Georgia. Clones tested were primarily U.S. Department of Agriculture selections, but two grower-discovered cultivars, Jubilee and Surprize, were also trialed. Annual yields were measured for each tree in the test throughout the test period and the alternate bearing intensity of each cultivar was calculated. Average annual in-shell nut production in years 1-10 ranged from $12 \mathrm{lb}$ in the precocious USDA 76-4-41 to $0 \mathrm{lb}$ in the non-precocious USDA 72-8-4. Wide variation was seen in nut production of trees in years 11-18, averaging from 10 to $60 \mathrm{lb}$ nut yield per year. A subsample of nuts was taken from each tree annually and percent kernel, nuts per pound, specific gravity, and nut volume were determined. Significant differences were found between clones for each of these traits. Differences were also found for the presence of damage from pecan scab [Fusicladium effusum (synonym Cladosporium caryigenum)] and black pecan aphid (Melanocallis caryaefoliae). Most clones were not acceptable for use in Georgia due to small nut size or poor kernel quality, but two clones merit further testing in this region. USDA 70-3-34 produced a large nut with good quality and scab resistance, but needs to be evaluated with mechanical crop thinning to improve kernel quality in high crop-set years. USDA 74-1-12 produced good yields of excellent quality, medium-sized pecans and should be trialed with greater tree numbers. Several other clones were found to have traits of interest to pecan breeding programs including: pecan scab resistance, large nut size, and high kernel percentage. Results of this trial suggest that cultivar development programs in Georgia should place greater selection emphasis on large nut size.

$\mathrm{P}$ ecan is a native North American crop and is the most economically important member of the Carya genus. Georgia is the leading pecan producing state, with the majority of acreage located in the

Department of Horticulture, University of GeorgiaTifton Campus, 2360 Rainwater Road, Tifton, GA 31793-5766

This project was funded in part by the Georgia Commodity Commission for Pecan.

The author gratefully acknowledges the USDA pecan breeding program for providing the germplasm used in this evaluation.

${ }^{1}$ Corresponding author. E-mail: pconner@uga.edu. southern half of the state. Pecans are one of Georgia's most valuable horticultural crops with over 144,000 acres of pecan orchards and a farm-gate value over \$249 million in 2012 (U.S. Department of Agriculture, 2013). The Georgia production environment is typified by hot, humid summers and relatively mild winters. Because of the large amount of rainfall in the summer, pecan cultivars must have at least moderate levels of resistance to pecan scab to enable disease control with a fungicide spray program.

Pecan trees require several years of growth before producing a harvestable crop, and several more years to come into full bearing. However, after establishment, pecan trees are an extremely long-lived crop, and orchards over 90 years old are still bearing and productive. Once pecan trees are in place, it is very expensive to replace them, making cultivar choice an extremely important decision. Replicated trials of new cultivars help prevent growers from making costly mistakes in orchard establishment. The University of Georgia-Tifton Campus has been involved in pecan cultivar testing for over 93 years (Worley and Mullinix, 1994). More recently, it has been a testing location for the National Pecan Advanced Clone Testing System (NPACTS). This system tests advanced pecan selections from the USDA breeding program at various locations across the pecan belt (Thompson and Conner, 2012). Selections that perform well in NPACTS testing may then be released as new cultivars by the USDA.

Two cultivars, Stuart and Desirable, make up over half of the mature trees in commercial orchards in Georgia (Florkowski et al., 1999). Both of these cultivars were developed over 80 years ago, when production practices differed greatly from current methods. 'Stuart' continues to be common as a mature tree in Georgia, but new plantings are not recommended because of its low precocity, relatively poor kernel quality, and loss of disease resistance (Wells and Conner, 2012). 'Desirable' is the most widely planted

\begin{tabular}{llll}
\hline $\begin{array}{l}\text { Unit } \\
\text { To convert U.S. to SI, } \\
\text { multiply by }\end{array}$ & U.S. unit & SI unit & $\begin{array}{l}\text { To convert SI to U.S., } \\
\text { multiply by }\end{array}$ \\
\hline 0.4047 & $\mathrm{acre}(\mathrm{s})$ & $\mathrm{ha}$ & 2.4711 \\
100 & $\mathrm{bar}$ & $\mathrm{kPa}$ & 0.01 \\
0.3048 & $\mathrm{ft}$ & $\mathrm{m}$ & 3.2808 \\
3.7854 & $\mathrm{gal}$ & $\mathrm{L}$ & 0.2642 \\
16.3871 & inch & $\mathrm{cm}^{3}$ & 0.0610 \\
0.4536 & $\mathrm{lb}$ & $\mathrm{kg}$ & 2.2046 \\
1.1209 & $\mathrm{lb} / \mathrm{acre}$ & $\mathrm{kg} \cdot \mathrm{ha}^{-1}$ & 0.8922
\end{tabular}


cultivar in Georgia (Wells, 2013). 'Desirable' is popular because it has consistent production of large nuts with excellent shelling ability and light golden kernel color (Wells and Conner, 2012). However, 'Desirable' is very susceptible to pecan scab, and growers are actively searching for more resistant alternatives with a similar or superior nut quality (Goff et al., 2003).

Pecan cultivars are propagated clonally by grafting the scion cultivar onto a seedling rootstock. Superior pecan cultivars have been selected only since the mid-19th century, compared with thousands of years for many crop plants. Pecan cultivars have three different origins: chance seedlings, selections from seedling orchards or seeds planted by homeowners, and breeding programs (Sparks 1992). Systematic pecan breeding has been ongoing since the 1940s and has resulted in the release of many new cultivars with substantial improvement in key horticultural characteristics. The USDA has operated the longest standing pecan breeding program from its Brownwood, TX station (Thompson and Conner, 2012). Several selections from the USDA breeding program have been trialed at Tifton, GA, and subsequently released as new cultivars for use in Georgia (Conner and Thompson, 2003; Thompson and Hunter, 1985; Thompson et al., 1996, 1997).

This report analyzes the production and quality aspects of 19 pecan clones in the experimental orchards at Tifton, GA. These clones are predominantly unreleased USDA breeding program selections, but also include two unpatented grower selections. This test was designed to determine if these clones warrant recommendation in southern Georgia as new cultivars, as well as to determine which clones have traits potentially useful to pecan breeding programs.

\section{Materials and methods}

The test orchard is located in western Tift County, GA (lat. 31 ${ }^{\circ} 30^{\prime} 29.13^{\prime \prime}$ $\mathrm{N}$, long. $\left.83^{\circ} 39^{\prime} 4.49^{\prime \prime} \mathrm{W}\right)$. Parentage of the USDA selections is listed in Table 1. Two unpatented cultivars, Jubilee and Surprize (Goff et al., 1991) were also tested. These clones were chosen for inclusion based on grower and breeder observations from other locations. This test orchard was developed for the NPACTS program in 1979 , and

Table 1. Number of trees evaluated, year(s) planted and parentage of pecan cultivars or selections tested at Tifton, GA, in 1989-2008.

\begin{tabular}{lcll}
\hline Clone & Trees (no.) & Yr(s) planted & \multicolumn{1}{c}{ Parentage $^{\mathrm{z}}$} \\
\hline USDA 70-10-50 & 3 & 1991 & 'Wichita' $\times$ 'Cheyenne' \\
USDA 70-3-34 & 2 & 1991 & 'Shoshoni' $\times$ 'Cheyenne' \\
USDA 70-4-9 & 2 & 1991 & 'Cherokee' $\times$ 'Cheyenne' \\
USDA 70-6-15 & 4 & 1991 & 'Kiowa' $\times$ 'Desirable' \\
USDA 72-10-5 & 2 & 1991 & 'Riverside' $\times$ 'Apache' \\
USDA 72-2-9 & 4 & 1991 & 'Cherokee' $\times$ 'Cape Fear' \\
USDA 72-5-8 & 3 & 1991,1992 & 'Osage' $\times$ 'Cheyenne' \\
USDA 72-6-12 & 2 & 1991 & 'Shoshoni' $\times$ USDA 49-23-16 \\
USDA 72-6-36 & 3 & 1991 & 'Shoshoni' $\times$ USDA 49-23-16 \\
USDA 72-8-4 & 2 & 1991 & 'Cheyenne' $\times$ 'Sioux' \\
USDA 73-1-10 & 3 & 1991 & 'Western Schley' $\times$ USDA 57-7-22 \\
USDA 74-1-12 & 2 & 1991 & 'Appalachee' $\times$ 'Wichita' \\
USDA 74-4-3 & 4 & 1991 & 'Chickasaw' $\times$ 'Cheyenne' \\
USDA 75-5-32 & 2 & 1991 & 'Cheyenne' $\times$ 'Sioux' \\
USDA 76-4-44 & 4 & 1991,1992 & 'Shoshoni' $\times$ 'Cape Fear' \\
USDA 76-7-41 & 4 & 1991,1993 & 'Shoshoni' $\times$ 'Cape Fear' \\
USDA 78-15-51 & 4 & 1991 & 'Shawnee' $\times$ 'Cheyenne' \\
'Jubilee' & 3 & 1989 & Seedling \\
'Surprize' & 4 & 1992,1994 & Seedling \\
\hline
\end{tabular}

${ }^{2}$ Seedling denotes trees planted by man where one or both parents are unknown.

the orchard was expanded with new selections in 1981 and in 1991. The priority of this testing program is to evaluate genotypes for potential use in the breeding program or for suitability as new cultivars. The orchard is managed to mimic the care that would be given to a well-managed commercial orchard.

The majority of the trees in this test were planted in 1991; however, 'Jubilee' trees were planted in 1989 and a few other trees were replanted in 1992-94 due to tree deaths (Table 1). Two to four trees were evaluated for each clone (Table 1). Trees were planted into a single orchard block at a spacing of $40 \times 40 \mathrm{ft}$ ( 27 trees/acre), with tree location randomized within the year planted. Nitrogen was applied annually at $100 \mathrm{lb} /$ acre, while other nutrients and lime were applied according to leaf or soil analysis. Microsprinkler irrigation was used with one 20 -gal/h microsprinkler per tree applying water when the matric potential reached -0.1 bar. Fungicides were applied routinely according to University of Georgia recommendations (Ellis et al., 2000), and insecticides were applied only when an insect buildup occurred.

Each tree was harvested yearly for total nut yield, and a random 50nut sample was collected from each tree to measure nut quality. Nut volume was determined by water displacement. Specific gravity is the average nut volume/average nut weight. Nuts were shelled and percentage edible kernel was calculated by weight. The fluctuation in yield from year to year was expressed as alternate bearing intensity $(I)$, a measure of intensity of deviation in yield in successive years (Pearce and Doberšek-Urbanc, 1967). $I=1 /(\mathrm{n}-\mathrm{l}) \times\left\{\left|\left(\mathrm{a}_{2}-\mathrm{a}_{1}\right)\right| /\left(\mathrm{a}_{2}+\mathrm{a}_{1}\right)+\right.$ $\left|\left(a_{3}-a_{2}\right)\right| /\left(a_{3}+a_{2}\right) \ldots+\mid\left(a_{(n)}-a_{(n-1)} \mid /\right.$ $\left(\mathrm{a}_{(\mathrm{n})}+\mathrm{a}_{(\mathrm{n}-\mathrm{l})}\right\}$, where $\mathrm{n}=$ number of years, and $a_{1}, a_{2}, \ldots, a_{(n-1)}, a_{n}=$ yield of corresponding years. I varies from a maximum of one which indicates no yield every other year, to a minimum of zero, indicating identical yields each year. I was calculated using eight to ten years of data beginning in year nine and ending with the final yield. Nuts were harvested when about $90 \%$ could be shaken from the tree with a mechanical shaker. Harvest date was determined by averaging the day of the year each cultivar was harvested from 1998 to 2008.

Annual pest evaluations were completed in early September in years 1999 to 2006. Each tree was evaluated for leaf scab using a four-point scale with the maximum level of infection scored: $1=$ no scab lesions, 2 = a few isolated lesions with restricted growth, $3=$ multiple lesions with expanding growth, and $4=$ stem scab lesions or defoliation. Nut scab was scored using a five-point scale 
with the maximum level of infection scored: 1 = no scab lesions, 2 = a few lesions with restricted growth, $3=$ multiple lesions, $0 \%$ to $10 \%$ coverage, $4=11 \%$ to $50 \%$ coverage, and $5=$ $51 \%$ to $100 \%$ coverage or nut drop. Black pecan aphid damage was rated on a four-point scale observing the lower interior of the canopy: $1=$ no damage, 2 = light chlorotic spotting, $0 \%$ to $25 \%$ leaves affected, $3=$ moderate chlorotic spotting, $26 \%$ to $75 \%$ leaves affected, and $4=$ heavy chlorotic spotting, $76 \%$ to $100 \%$ leaves affected. Sooty mold accumulation was rated on the lower interior canopy using a four-point scale: $1=$ no accumulation, 2 = light accumulation, some black on a few leaves, $3=$ moderate accumulation, black on most leaves, and $4=$ heavy accumulation, black flaking on stems and leaves.

Yield and quality data for each year of growth were calculated for each clone by averaging the values of all the replicate trees of that clone for the given year. Clone values for quality characteristics were calculated by averaging all years. Average trait values for each clone were subjected to one- way analysis of variance procedures and mean separation by Duncan's multiple range test $(P=0.05)$ using SigmaStat (Systat Software, San Jose, CA) statistical software. Associations between leaf and nut scab were determined by Pearson product moment correlation.

\section{Results and discussion}

Yields were averaged for years 1 to 10 and 11 to 20 . Yield in years 1 to 10 gives a representation of yield as trees are transitioning from an immature unfruitful stage to mature fruiting trees. Precocious trees with heavy early yields are advantageous because an economic return on the orchard investment is realized sooner (Grauke and Thompson, 1996). However, precocity in some cultivars is linked to irregular bearing in mature trees (Sparks, 1990). Average yield in years 1 to 10 ranged from 0 to $12 \mathrm{lb}$ per year (Table 2). In a previous trial planted in 1981, the standard cultivars Pawnee and Sumner averaged 8 and $9 \mathrm{lb}$ per year, respectively, in the same orchard with similar care (Conner and Worley, 2002). The cultivar Creek, which was released in part due to its

Table 2. Annual in-shell nut yield, alternate bearing intensity $(I)$, and kernel yield of pecan cultivars or selections at Tifton, GA, in 1989-2008.

\begin{tabular}{|c|c|c|c|c|c|}
\hline \multirow[b]{2}{*}{ Clone } & \multicolumn{2}{|c|}{ In-shell nut yield (lb/tree $)^{\mathrm{z}}$} & \multirow[b]{2}{*}{$I^{\mathrm{y}}$} & \multicolumn{2}{|c|}{ Kernel yield (lb/tree) } \\
\hline & $\begin{array}{c}\text { Avg years } \\
1-10\end{array}$ & $\begin{array}{c}\text { Avg years } \\
11-18\end{array}$ & & $\begin{array}{c}\text { Avg years } \\
1-10\end{array}$ & $\begin{array}{c}\text { Avg years } \\
11-18\end{array}$ \\
\hline USDA 70-10-50 & $3 \operatorname{def}^{x}$ & $20 \mathrm{~d}-\mathrm{g}$ & $0.73 \mathrm{bc}$ & 1 cde & $11 \mathrm{def}$ \\
\hline USDA 70-3-34 & $9 \mathrm{abc}$ & $60 \mathrm{a}$ & $0.86 \mathrm{abc}$ & $5 \mathrm{ab}$ & $33 \mathrm{a}$ \\
\hline USDA 70-4-9 & $2 \mathrm{ef}$ & $28 \mathrm{c}-\mathrm{g}$ & $0.83 \mathrm{abc}$ & $1 \mathrm{de}$ & $14 c-f$ \\
\hline USDA 70-6-15 & $6 \mathrm{bcd}$ & $54 \mathrm{ab}$ & $0.64 \mathrm{c}$ & $4 \mathrm{bc}$ & $32 \mathrm{a}$ \\
\hline USDA 72-10-5 & $11 \mathrm{a}$ & $37 \mathrm{~b}-\mathrm{e}$ & $0.86 \mathrm{abc}$ & $5 \mathrm{ab}$ & $19 \mathrm{~b}-\mathrm{e}$ \\
\hline USDA 72-2-9 & $10 \mathrm{ab}$ & 42 bcd & $0.74 \mathrm{bc}$ & $5 \mathrm{ab}$ & $21 \mathrm{bc}$ \\
\hline USDA 72-5-8 & $5 c-f$ & 38 bcd & $0.42 \mathrm{c}$ & 2 cde & $20 \mathrm{bcd}$ \\
\hline USDA 72-6-12 & $4 c-f$ & $36 \mathrm{~b}-\mathrm{e}$ & $0.84 \mathrm{abc}$ & 2 cde & $19 \mathrm{~b}-\mathrm{e}$ \\
\hline USDA 72-6-36 & $4 c-f$ & 35 cde & $0.67 \mathrm{bc}$ & 2 cde & 17 cde \\
\hline USDA 72-8-4 & $0 \mathrm{f}$ & $10 \mathrm{~g}$ & $0.91 \mathrm{ab}$ & $0 \mathrm{e}$ & $5 \mathrm{f}$ \\
\hline USDA 73-1-10 & 3 def & $15 \mathrm{fg}$ & $0.63 \mathrm{c}$ & 2 cde & 9 ef \\
\hline USDA 74-1-12 & $10 \mathrm{ab}$ & $48 \mathrm{abc}$ & $0.33 \mathrm{~d}$ & $6 \mathrm{a}$ & $28 \mathrm{ab}$ \\
\hline USDA 74-4-3 & $3 \mathrm{def}$ & $27 \mathrm{~d}-\mathrm{g}$ & $0.75 \mathrm{bc}$ & 2 cde & 15 cde \\
\hline USDA 75-5-32 & $11 \mathrm{ab}$ & $44 \mathrm{a}-\mathrm{d}$ & $0.89 \mathrm{abc}$ & $5 \mathrm{ab}$ & $22 \mathrm{bc}$ \\
\hline USDA 76-4-44 & $12 \mathrm{a}$ & $47 \mathrm{abc}$ & $0.95 \mathrm{a}$ & $6 a$ & $22 \mathrm{bc}$ \\
\hline USDA 76-7-41 & $4 \mathrm{def}$ & 34 cde & $0.69 \mathrm{bc}$ & 2 cde & 17 cde \\
\hline USDA 78-15-51 & $4 c-f$ & 35 cde & $0.66 \mathrm{c}$ & 2 cde & $19 \mathrm{~b}-\mathrm{e}$ \\
\hline 'Jubilee' & 2 ef & $31 \mathrm{c}-\mathrm{f}$ & $0.80 \mathrm{abc}$ & $1 \mathrm{de}$ & $12 c-f$ \\
\hline 'Surprize' & 5 cde & 一 $^{\mathrm{w}}$ & $0.34 \mathrm{~d}$ & $2 \mathrm{~cd}$ & 一 $^{\mathrm{w}}$ \\
\hline Significance & $P<0.001$ & $P<0.001$ & $P<0.001$ & $P<0.001$ & $P<0.001$ \\
\hline
\end{tabular}

${ }^{\mathrm{z}} 1 \mathrm{lb}=0.4536 \mathrm{~kg}$.

${ }^{y} 1=$ no crop in alternate years, $0=$ identical crop in alternate years. Calculated using in-shell nut yields from year nine to final yield.

'Mean separation within columns by Duncan's multiple range test at $P \leq 0.05$. Values sharing a common letter are not statistically different.

"Yields for 'Surprize' were not included because the cultivar was planted later than the other clones. precocity (Thompson et al., 1996), averaged $11 \mathrm{lb}$ per year in the 1981 study. Many of the selections in this test appear to be nonprecocious as they averaged $4 \mathrm{lb}$ or less in years 1 to 10. This was somewhat surprising given that many of the parents of these selections including: 'Wichita', 'Cheyenne', 'Shoshoni', 'Cape Fear', and 'Chickasaw' are precocious cultivars (Sparks, 1992).

In the 1981 trial, 'Pawnee' and 'Sumner' averaged 48 and $46 \mathrm{lb}$ per year, respectively, while the highly prolific 'Candy' averaged $55 \mathrm{lb}$ per year in years 11 to 20 (Conner and Worley, 2002). In this trial, nut yields in years 11 to 18 varied from 10 to $60 \mathrm{lb}$ per year (Table 2). Kernel yield rankings were generally similar to inshell nut yield rankings. Pecan yield trials are particularly sensitive to the constraints of the experimental organism. The perennial nature of the crop means that damage to the tree such as limb breakage or trunk injuries are carried through from one year to the next, as are effects coming from site differences within the orchard. The large size of the tree also often necessitates that a smaller than optimum number of plants are used to estimate yields. For these reasons, yield estimates based on a small number of trees should be used to broadly classify clones according to potential precociousness and mature tree yield potential rather than to narrowly rank clones for predicted yield. Despite these limitations, clones at the bottom of the yield rankings, including USDA 70-10-50, USDA 70-4-9, USDA 72-8-4, USDA 73-1-10, and USDA 74-4-3, likely will not yield enough to be profitable.

Clones varied in the reason for low yields. USDA 70-10-50 and USDA 73-1-10 were very susceptible to nut scab (Table 3 ), reducing yields in wet years. USDA 70-10-50, like its parent 'Wichita' (Sparks, 1990), was also very susceptible to water split, which reduced yields in some years. USDA 70-4-9 took a long time to come into production, and then strongly alternated in production. The other selections appeared to have low nut set.

$I$ provides a measure of a pecan cultivar's tendency to produce alternating high and low yields. $I$ ranged from a very low 0.33 in USDA 74-112 to 0.95 in USDA 76-4-44, which 
Table 3. Pest resistance of pecan cultivars or selections averaged over years 19992006 at Tifton, GA.

\begin{tabular}{lcccc}
\hline Clone & $\begin{array}{c}\text { Leaf scab } \\
(\mathbf{1}-\mathbf{4} \text { scale })^{\mathbf{z}}\end{array}$ & $\begin{array}{c}\text { Nut scab } \\
(\mathbf{1}-\mathbf{5} \text { scale })^{\mathbf{y}}\end{array}$ & $\begin{array}{c}\text { Black pecan } \\
\text { aphid damage } \\
(\mathbf{1}-\mathbf{4} \text { scale })^{\mathbf{x}}\end{array}$ & $\begin{array}{c}\text { Sooty mold } \\
\text { buildup } \\
(\mathbf{1 - 4} \text { scale })^{\mathbf{w}}\end{array}$ \\
\hline USDA 70-10-50 & $2.0 \mathrm{~b}^{\mathrm{v}}$ & $3.8 \mathrm{a}$ & $2.5 \mathrm{a}-\mathrm{d}$ & $2.7 \mathrm{abc}$ \\
USDA 70-3-34 & $1.0 \mathrm{~d}$ & $1.0 \mathrm{e}$ & $1.7 \mathrm{~d}$ & $2.4 \mathrm{~b}-\mathrm{e}$ \\
USDA 70-4-9 & $2.7 \mathrm{a}$ & $3.7 \mathrm{ab}$ & $2.1 \mathrm{~cd}$ & $2.6 \mathrm{a}-\mathrm{d}$ \\
USDA 70-6-15 & $1.0 \mathrm{~d}$ & $1.1 \mathrm{e}$ & $3.3 \mathrm{a}$ & $1.3 \mathrm{f}$ \\
USDA 72-10-5 & $1.2 \mathrm{~cd}$ & $1.6 \mathrm{de}$ & $2.1 \mathrm{~cd}$ & $2.7 \mathrm{abc}$ \\
USDA 72-2-9 & $1.0 \mathrm{~d}$ & $1.0 \mathrm{e}$ & $2.6 \mathrm{a}-\mathrm{d}$ & $1.3 \mathrm{f}$ \\
USDA 72-5-8 & $1.0 \mathrm{~d}$ & $1.0 \mathrm{e}$ & $3.2 \mathrm{ab}$ & $3.5 \mathrm{a}$ \\
USDA 72-6-12 & $1.0 \mathrm{~d}$ & $1.1 \mathrm{e}$ & $1.8 \mathrm{~d}$ & $3.1 \mathrm{ab}$ \\
USDA 72-6-36 & $2.6 \mathrm{a}$ & $3.3 \mathrm{~d}$ & $2.9 \mathrm{abc}$ & $2.8 \mathrm{abc}$ \\
USDA 72-8-4 & $1.0 \mathrm{~d}$ & $1.2 \mathrm{e}$ & $2.4 \mathrm{bcd}$ & $2.9 \mathrm{abc}$ \\
USDA 73-1-10 & $1.3 \mathrm{~cd}$ & $2.6 \mathrm{c}$ & $1.9 \mathrm{~d}$ & $1.6 \mathrm{def}$ \\
USDA 74-1-12 & $1.2 \mathrm{~cd}$ & $2.1 \mathrm{~cd}$ & $1.8 \mathrm{~d}$ & $2.0 \mathrm{a}-\mathrm{f}$ \\
USDA 74-4-3 & $1.8 \mathrm{~b}$ & $2.0 \mathrm{~cd}$ & $1.8 \mathrm{~d}$ & $2.5 \mathrm{bcd}$ \\
USDA 75-5-32 & $1.9 \mathrm{~b}$ & $2.6 \mathrm{c}$ & $2.1 \mathrm{~cd}$ & $2.3 \mathrm{~b}-\mathrm{e}$ \\
USDA 76-4-44 & $1.0 \mathrm{~d}$ & $1.1 \mathrm{e}$ & $1.9 \mathrm{~d}$ & $2.1 \mathrm{cde}$ \\
USDA 76-7-41 & $1.0 \mathrm{~d}$ & $1.9 \mathrm{~d}$ & $2.9 \mathrm{abc}$ & $1.6 \mathrm{ef}$ \\
USDA 78-15-51 & $1.4 \mathrm{c}$ & $2.2 \mathrm{~cd}$ & $2.6 \mathrm{a}-\mathrm{d}$ & $1.7 \mathrm{def}$ \\
'Jubilee' & $1.0 \mathrm{~d}$ & $1.0 \mathrm{e}$ & $2.9 \mathrm{abc}$ & $3.1 \mathrm{ab}$ \\
'Surprize' & $1.0 \mathrm{~d}$ & $1.2 \mathrm{e}$ & $2.2 \mathrm{~cd}$ & $3.2 \mathrm{ab}$ \\
Significance & $P<0.001$ & $P<0.001$ & $P<0.001$ & $P<0.001$ \\
\hline
\end{tabular}

${ }^{\mathrm{z}} 1$ = no scab lesions, 2 = a few isolated lesions with restricted growth, $3=$ multiple lesions with expanding growth, 4 $=$ stem scab lesions or defoliation.

${ }^{\mathrm{y}} \mathrm{l}=$ no scab lesions, $2=$ a few lesions with restricted growth, $3=$ multiple lesions, $0 \%$ to $10 \%$ coverage, $4=11 \%$ to $50 \%$ coverage, $5=51 \%$ to $100 \%$ coverage or nut drop.

${ }^{\mathrm{x}} \mathrm{l}=$ no damage, 2 = light chlorotic spotting, $0 \%$ to $25 \%$ leaves affected, $3=$ moderate chlorotic spotting, $26 \%$ to $75 \%$ leaves affected, $4=$ heavy chlorotic spotting, $76 \%$ to $100 \%$ leaves affected.

${ }^{\mathrm{w}} \mathrm{l}=$ no accumulation, 2 = light accumulation, some black on a few leaves, 3 = moderate accumulation, black on most leaves, $4=$ heavy accumulation, black flaking on stems and leaves.

"Mean separation within columns by Duncan's multiple range test at $P \leq 0.05$.

showed nearly complete alternation in yield from years 9 to 18 . Cultivars with $I$ values greater than 0.65 have been less likely to be accepted by the industry (Conner and Worley, 2000). However, in recent years, mechanical shaking of excess crop in the summer has been explored as a means of reducing $I$ in prolific cultivars (Smith and Gallott, 1990; Smith et al., 1993). It is possible that with mechanical crop load thinning, clones with high $I$ could be managed profitably (Wells et al., 2009). USDA 70-3-34 is a clone with a high tendency to alternate with poor quality in the "ON" year. However, this clone is capable of producing large nuts with good quality (Table 4) and has excellent pest resistance (Table $3)$. These traits make USDA 70-3-34 an excellent candidate for crop load thinning experiments.

Nut size was measured by weight (nuts per pound) and by volume (cubic centimeters). Nut weight ranged from 72.1 to 48.4 nuts/lb. Nut volume ranged from 8.8 to $13.8 \mathrm{~cm}^{3}$. Larger nuts are preferred in the Georgia marketplace given sufficient kernel quality. Nut size has become more important in recent years because of an increase in nuts being exported to China, which is a market that prefers a large-sized nut (Goff, 2012; Wells, 2013). The standard cultivar Desirable averages 48 nuts/lb (Wells and Conner, 2012), which brings a premium price in the current market. Generally, nuts smaller than 55 nuts/lb are not as highly valued in the marketplace, and cultivars that produce smaller nuts would have to be exceptional in other ways such as yield or earliness to be profitable. Unfortunately, many of the clones in this test had a medium to small nut weight. Ten of the clones in this test had a weight of 60 nuts/lb or less (Table 4). Only one of those, USDA 74-1-12, ranked among the top for percent kernel and yield (Tables 1 and $2)$. This clone also had the lowest $I$ (Table 1) and acceptable pest resistance (Table 3). USDA 74-1-12 appears to have some usefulness in this region, but the other small-sized clones do not appear to be valuable for the southeastern United States.
Given the relative ease of screening breeding program selections for nut size, and the importance of this trait in the current market, cultivar development programs in Georgia should place greater emphasis on nut size.

Kernel quality was measured by percent kernel and specific gravity. Percent kernel is a function of kernel development, shell thickness, and nut size, whereas specific gravity is a better indicator of kernel development (Dodge, 1944). However, due to the difficulty of measuring specific gravity, buyers use percent kernel to grade pecans. Over time, the trend has been to plant cultivars with higher kernel percentage. 'Stuart', the old standard for this region, averages $46 \%$ kernel, and the current standard, 'Desirable', averages $51 \%$ kernel (Wells and Conner, 2012). Most newly released cultivars recommended for this region have kernel percentages of $54 \%$ or greater (Wells and Conner, 2012), and the recent release 'Morrill' has a kernel percentage of 66\% (Sparks, 2010). Percent kernel of tested clones ranged from $46 \%$ to $59 \%$ and specific gravity ranged from 0.66 to 0.78 (Table 4). Seven clones had a percent kernel of $54 \%$ or greater, and four of those clones also had a nut size greater than 55 nuts/lb.

Earlier harvest dates often bring a premium price because nuts can be marketed before the Thanksgiving and Chinese New Year holidays (Goff, 2013). Many new cultivars in this region are attempting to fill the need for early harvest cultivars with harvest dates in mid-to-late September (Sparks, 2012; Thompson et al., 2007). Average harvest date for 'Desirable' in this region is 12 Oct. and 'Sumner', the main late harvest cultivar, is 29 Oct. (Wells and Conner, 2012). Harvest dates in the evaluated clones ranged from early midseason (10 Oct.) to relatively late $(30$ Oct.).

Pecan clones were evaluated for symptoms of pecan scab on both the leaves and the nuts. Leaf scab ratings ranged from 1.0 to 2.6 , and nut scab ratings ranged from 1.0 to 3.8 . Pecan scab ratings should be considered preliminary because a large number of races of the fungus exist (Conner and Stevenson, 2004), and testing in a single location may not expose the clone to a virulent race. Since only a few trees are planted to each selection, it is likely that scab levels in this 
Table 4. Comparison of pecan cultivars or selections nut quality data averaged overall testing years at Tifton, GA, 19892008.

\begin{tabular}{|c|c|c|c|c|c|}
\hline Clone & Nuts (no. /lb) $)^{z}$ & Kernel (\%) & Specific gravity & Nut volume $\left(\mathrm{cm}^{3}\right)^{\mathrm{z}}$ & Harvest date $^{\mathrm{y}}$ \\
\hline USDA 70-10-50 & $54.1 \mathrm{fg}^{\mathrm{x}}$ & $55.6 \mathrm{abc}$ & $0.73 \mathrm{bc}$ & $11.8 \mathrm{~d}$ & 11 Oct. e \\
\hline USDA 70-3-34 & $51.8 \mathrm{gh}$ & $53.8 \mathrm{bcd}$ & $0.73 \mathrm{bc}$ & $12.2 \mathrm{~cd}$ & 21 Oct. bc \\
\hline USDA 70-6-15 & $53.1 \mathrm{gh}$ & $58.9 \mathrm{a}$ & $0.73 \mathrm{bc}$ & $11.8 \mathrm{~d}$ & 19 Oct. cd \\
\hline USDA $72-10-5$ & 60.8 cde & $48.7 \mathrm{fgh}$ & $0.73 \mathrm{bc}$ & $10.5 \mathrm{efg}$ & 14 Oct. cde \\
\hline USDA 72-2-9 & $64.5 \mathrm{bc}$ & $52.4 \mathrm{c}-\mathrm{f}$ & $0.72 \mathrm{~cd}$ & $10.8 \mathrm{ef}$ & 10 Oct. e \\
\hline USDA 72-6-36 & $64.2 \mathrm{bcd}$ & $46.4 \mathrm{~h}$ & $0.68 \mathrm{def}$ & $10.8 \mathrm{ef}$ & 15 Oct. cde \\
\hline USDA $72-8-4$ & $72.1 \mathrm{a}$ & $53.4 \mathrm{~b}-\mathrm{e}$ & $0.67 \mathrm{def}$ & $9.5 \mathrm{gh}$ & 27 Oct. ab \\
\hline USDA 73-1-10 & $60.0 \mathrm{cde}$ & $56.3 \mathrm{ab}$ & $0.77 \mathrm{a}$ & $10.0 \mathrm{fg}$ & 21 Oct. bc \\
\hline USDA 74-1-12 & $63.3 \mathrm{~b}-\mathrm{c}$ & $57.9 \mathrm{ab}$ & $0.78 \mathrm{a}$ & $9.4 \mathrm{gh}$ & 14 Oct. cde \\
\hline USDA 74-4-3 & $70.0 \mathrm{a}$ & $56.5 \mathrm{ab}$ & $0.75 \mathrm{ab}$ & $8.8 \mathrm{~h}$ & 11 Oct. e \\
\hline USDA 75-5-32 & $69.5 \mathrm{ab}$ & $49.1 \mathrm{e}-\mathrm{h}$ & 0.70 cde & $9.8 \mathrm{fgh}$ & 16 Oct. cde \\
\hline 'Jubilee' & $52.2 \mathrm{gh}$ & $46.7 \mathrm{gh}$ & $0.68 \mathrm{def}$ & $13.4 \mathrm{ab}$ & 19 Oct. cd \\
\hline 'Surprize' & $48.4 \mathrm{~h}$ & $49.7 \mathrm{e}-\mathrm{h}$ & 0.69 def & $13.8 \mathrm{a}$ & 30 Oct. a \\
\hline Significance & $P<0.001$ & $P<0.001$ & $P<0.001$ & $P<0.001$ & $P<0.001$ \\
\hline
\end{tabular}

${ }^{\mathrm{z}} \mathrm{l}$ nut $/ \mathrm{lb}=2.2046$ nuts $/ \mathrm{kg}, \mathrm{l} \mathrm{cm} \mathrm{cm}^{3}=0.0610 \mathrm{inch}^{3}$.

yAverage harvest date of 'Stuart' at this location was 17 Oct. Harvest date was averaged over years 1998-2008.

${ }^{x}$ Mean separation within columns by Duncan's multiple range test at $P \leq 0.05$.

test are lower than would be expected had a large block of trees been planted to a single cultivar. Leaf scab and nut scab ratings were highly correlated (0.862, $P<0.001)$. Three selections, USDA 70-10-50, USDA 70-4-9, and USDA 72-6-36, had leaf scab ratings greater than 2 and nut scab ratings greater than 3, and these clones would likely be highly susceptible to scab in a large planting in this region.

Black pecan aphid and yellow aphid complex [black margined aphid (Monellia caryell) and yellow pecan aphid (Monelliopsis pecanis)] are major entomological pests of pecan (Thompson and Conner, 2012). Black pecan aphid is often the most economically significant of the pecan aphids that attack pecan (Tedders, 1978). Feeding produces the formation of chlorotic blotches that can coalesce and result in defoliation, reducing photosynthetic capacity. Susceptibility to black pecan aphid can be identified by observation of chlorosis on the tree leaves (Wood and Reilly, 1998). Black pecan aphid damage ratings ranged from 1.7 to 3.3 (Table 3 ). The majority of the damage from yellow aphid complex is caused by deposition of honeydew on leaf surfaces leading to the growth of a fungal mat (sooty mold), which reduces leaf photosynthesis (Tedders and Smith, 1976).

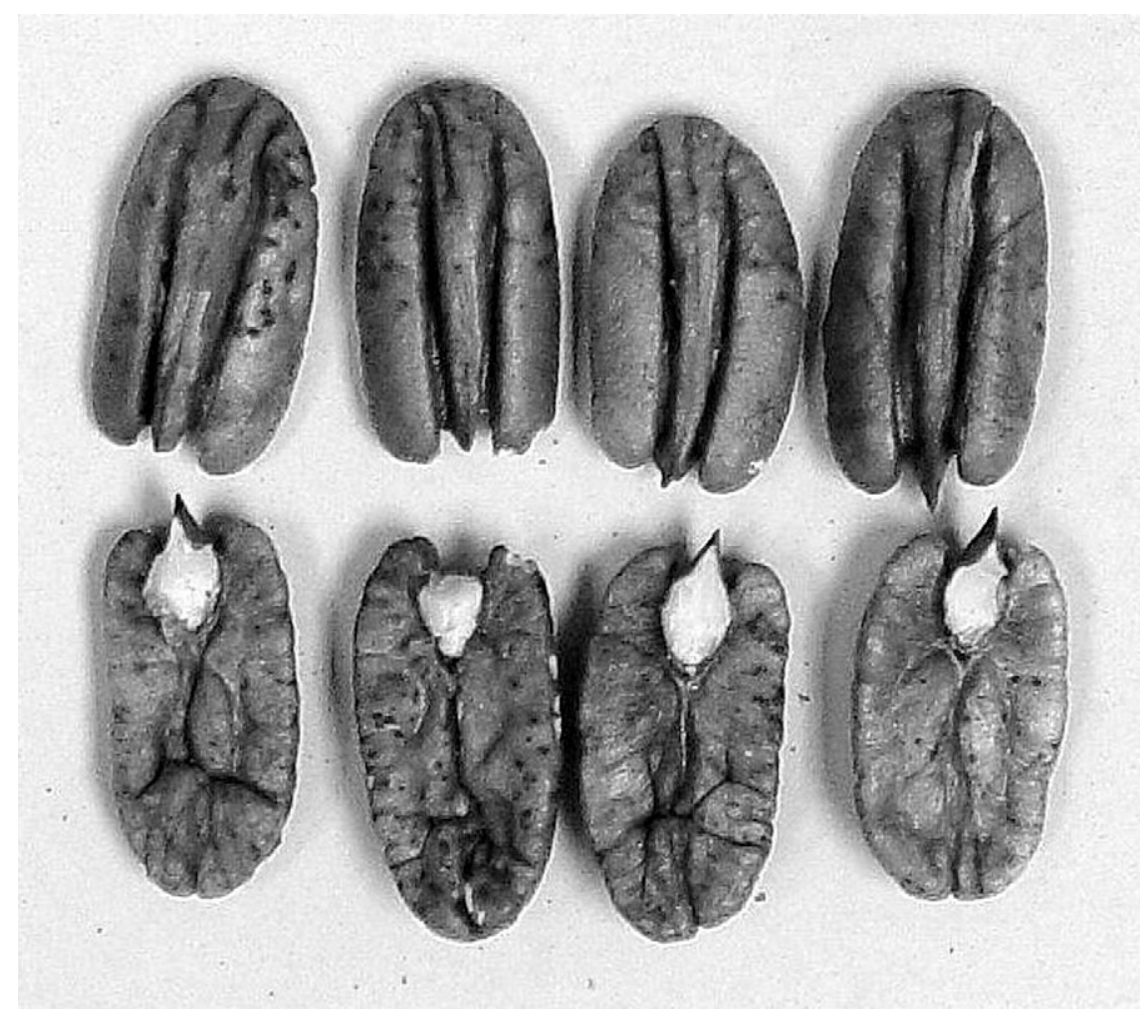

Fig. 1. USDA 70-6-15 pecan kernels showing the presence of kernel spotting.

Adherence of the fungal mat appears to be controlled by leaf surface morphology, which varies among cultivars (Sparks and Yates, 1991). Thus, sooty mold accumulation is governed by the number of aphids feeding on the tree as well as the morphology of the leaf surface. Sooty mold buildup ratings ranged from 1.3 to 3.5 . Black pecan aphid damage ratings were not 
correlated with sooty mold buildup (data not shown), and only two clones, USDA 73-1-10 and USDA 74-1-12, had ratings at 2.0 or below for both traits.

\section{Conclusion}

None of the 17 clones in this test have been recommended for release in Georgia. One clone, USDA 70-615 , entered grower trials due to its large nut size and excellent percent kernel. However, trials were discontinued due to the appearance of kernel spotting of unknown etiology in some years (Fig. 1). Two other clones have results promising enough to warrant further trials. USDA 70-334 had excellent, but alternating, yields of large nuts with acceptable percent kernel. In addition, pecan scab was never observed on this selection, and it also had good resistance to black pecan aphid damage. Although kernel quality was low in heavy-bearing years, the use of mechanical crop thinning may be able to ameliorate this loss of quality and improve return fruit set. USDA 74-1-12 produced good yields of excellent quality pecans. Although nut size was smaller than optimum in the Georgia market, the excellent kernel quality and good pest resistance of this clone warrants further yield testing with larger tree numbers. Even though the other clones did not possess the combination of traits needed for a new commercial cultivar, some had traits of interest to pecan breeding programs. Several clones had excellent resistance to pecan scab in this test and should be investigated as possible sources of resistance for breeding programs. In addition, USDA 70-6-15 and USDA 78-15-51 have been used in the UGA pecan breeding program as sources of large nut size and good kernel quality.

\section{Literature cited}

Conner, P.J. and K.L. Stevenson. 2004. Pathogenic variation of Cladosporium caryigenum isolates and corresponding differential resistance in pecan. HortScience 39:553-557.

Conner, P.J. and T.E. Thompson. 2003. Evaluation of nine pecan cultivars and selections in southern Georgia. J. Amer. Pomol. Soc. 57:115-120.
Conner, P.J. and R.E. Worley. 2000. Alternate bearing intensity of pecan cultivars. HortScience 35:1067-1069.

Conner, P.J. and R.E. Worley. 2002. Performance of 15 pecan cultivars and selections through 20 years in southern Georgia. HortTechnology 12:274-281.

Dodge, F.N. 1944. A method of measuring the degree of kernel development of samples of pecans. Proc. Amer. Soc. Hort. Sci. 45:151-157.

Ellis, H.C., P. Bertrand, and T.F. Crocker. 2000. Georgia pecan pest management guide. Univ. Georgia, College Agr. Environ. Sci., Athens.

Florkowski, W.J., T.F. Crocker, and G. Humphries. 1999. Commercial pecan tree inventory, Georgia, 1997. Univ. Georgia, College Agr. Environ. Sci., Georgia Expt. Sta. Res. Rpt. 678.

Goff, W. 2012. Planting southeastern orchards for the export market. Pecan South 45(10):4, 10-11.

Goff, W. 2013. Pecan cultivar recommendations for the Southeast - 2013 update. Pecan South 46(1):6, 11-19.

Goff, W., M. Nesbitt, and C. Browne. 2003. Incidence of scab and foliage condition on pecan cultivars grown without fungicide or insecticide sprays in a humid environment. HortTechnology 13:381384.

Goff, W., E. Tunnell, and R. McDaniel. 1991. The 'Surprize' pecan. Fruit Var. J. 45:180-185.

Grauke, L. and T. Thompson. 1996. Pecans and hickories, p. 185-239. In: J. Janick and J.N. Moore (eds.). Fruit breeding. Vol. III. Nuts. Wiley, New York, NY.

Pearce, S. and S. Doberšek-Urbanc. 1967. The measurement of irregularity in growth and cropping. J. Hort. Sci. 42:295-305.

Smith, M. and J. Gallott. 1990. Mechanical thinning of pecan fruit. HortScience 25:414-416.

Smith, M., W. Reid, B. Carroll, and B. Cheary. 1993. Mechanical fruit thinning influences fruit-quality, yield, return fruit-set, and cold injury of pecan. HortScience 28:1081-1084.

Sparks, D. 1990. Inter-relationship in precocity, prolificacy, and percentage kernel in pecan. HortScience 25:297-299.

Sparks, D. 1992. Pecan cultivars: The orchards foundation. Pecan Production Innovations, Watkinsville, GA.
Sparks, D. 2010. Introducing a pecan with exceptional kernel quality - 'Morrill' Pecan Grower 22(2):22-29.

Sparks, D. 2012. Early performance of 'Byrd' and 'Cunard' pecans. Pecan Grower 23(4):42-43.

Sparks, D. and I. Yates. 1991. Pecan cultivar susceptibility to sooty mold related to leaf surface morphology. J. Amer. Soc. Hort. Sci. 116:6-9.

Tedders, W. 1978. Important biological and morphological characteristics of the foliar-feeding aphids of pecan. U.S. Dept. Agr. Tech. Bul. 1579.

Tedders, W. and J. Smith. 1976. Shading effect on pecan by sooty mold growth. J. Econ. Entomol. 69:551-553.

Thompson, T. and P. Conner. 2012. Pecan, p. 771-801. In: M. Badeness and D. Byrne (eds.). Fruit breeding. Springer, New York, NY.

Thompson, T. and R. Hunter. 1985. 'Pawnee' pecan. HortScience 20:776.

Thompson, T., W. Goff, M. Nesbitt, R. Worley, R. O'Barr, and B. Wood. 1996. USDA releases two new cultivars: 'Creek' and 'Kanza' Pecan South 29(2):2-7.

Thompson, T., W. Goff, M. Nesbitt, R. Worley, R. O'Barr, and B. Wood. 1997. 'Creek' pecan. HortScience 32:141-143.

Thompson, T., L. Grauke, and W. Reid. 2007. 'Lakota' pecan. HortScience 43:250-251.

U.S. Department of Agriculture. 2013. Noncitrus fruits \& nuts 2012 preliminary summary, January 2013. Agr. Stat. Board, Natl. Agr. Stat. Serv., U.S. Dept. Agr., Washington, D.C.

Wells, M. 2013. 2012 has been an interesting year. Pecan Grower 14(3):4-7.

Wells, M., D. Carlson, and R. Philip. 2009. Profitability of mechanical fruit thinning of 'Sumner' and 'Cape Fear' pecan. HortTechnology 19:518-520.

Wells, M. and P. Conner. 2012. Pecan varieties for Georgia orchards. Univ. Georgia Circ. 898.

Wood, B. and C. Reilly. 1998. Susceptibility of pecan to black pecan aphids. HortScience 33:798-801.

Worley, R.E. and B.G. Mullinix. 1994. Pecan cultivar performance at the Coastal Plain Experiment Station, 1921-1994. Georgia Agr. Expt. Sta. Bul. 426. 